\title{
The Function of Selenium in Central Nervous System: Lessons from MsrB1 Knockout Mouse Models
}

\author{
Tengrui Shi ${ }^{1,2}$, Jianxi Song ${ }^{1}$, Guanying You ${ }^{1}$, Yujie Yang ${ }^{1}$, Qiong Liu ${ }^{1,3}$ and Nan Li ${ }^{1,4, * \mathbb{D}}$ \\ 1 Shenzhen Key Laboratory of Marine Biotechnology and Ecology, College of Life Sciences and Oceanography, \\ Shenzhen University, Shenzhen 518055, China; 18792600863@163.com (T.S.); \\ 1800251022@email.szu.edu.cn (J.S.); 2060251029@email.szu.edu.cn (G.Y.); \\ yangyujie2016@email.szu.edu.cn (Y.Y.); liuqiong@szu.edu.cn (Q.L.) \\ 2 The Central Laboratory, Shenzhen Second People's Hospital, the First Affiliated Hospital of Shenzhen \\ University Health Science Center, Shenzhen 518035, China \\ 3 Shenzhen-Hong Kong Institute of Brain Science, Shenzhen 518060, China \\ 4 Shenzhen Bay Laboratory, Shenzhen 518055, China \\ * Correspondence: lin@szu.edu.cn; Tel.: +86-13715189671; Fax: +86-(0)75526536629
}

Citation: Shi, T.; Song, J.; You, G.; Yang, Y.; Liu, Q.; Li, N. The Function of Selenium in Central Nervous System: Lessons from MsrB1 Knockout Mouse Models. Molecules 2021, 26, 1372. https://doi.org/ $10.3390 /$ molecules 26051372

Academic Editor: Arun Sharma

Received: 31 January 2021

Accepted: 25 February 2021

Published: 4 March 2021

Publisher's Note: MDPI stays neutral with regard to jurisdictional claims in published maps and institutional affiliations.

Copyright: (c) 2021 by the authors. Licensee MDPI, Basel, Switzerland. This article is an open access article distributed under the terms and conditions of the Creative Commons Attribution (CC BY) license (https:// creativecommons.org/licenses/by/ $4.0 /)$.

\begin{abstract}
MsrB1 used to be named selenoprotein $\mathrm{R}$, for it was first identified as a selenocysteine containing protein by searching for the selenocysteine insert sequence (SECIS) in the human genome. Later, it was found that MsrB1 is homologous to PilB in Neisseria gonorrhoeae, which is a methionine sulfoxide reductase (Msr), specifically reducing L-methionine sulfoxide (L-Met-O) in proteins. In humans and mice, four members constitute the Msr family, which are MsrA, MsrB1, MsrB2, and MsrB3. MsrA can reduce free or protein-containing L-Met-O (S), whereas MsrBs can only function on the L-Met-O $(R)$ epimer in proteins. Though there are isomerases existent that could transfer L-Met-O $(S)$ to L-Met-O $(R)$ and vice-versa, the loss of Msr individually results in different phenotypes in mice models. These observations indicate that the function of one Msr cannot be totally complemented by another. Among the mammalian Msrs, MsrB1 is the only selenocysteine-containing protein, and we recently found that loss of MsrB1 perturbs the synaptic plasticity in mice, along with the astrogliosis in their brains. In this review, we summarized the effects resulting from Msr deficiency and the bioactivity of selenium in the central nervous system, especially those that we learned from the MsrB1 knockout mouse model. We hope it will be helpful in better understanding how the trace element selenium participates in the reduction of L-Met-O and becomes involved in neurobiology.
\end{abstract}

Keywords: selenium; MsrB1; central nervous system; redox; synaptic plasticity

\section{Introduction}

The oxidation of free L-methionine (L-Met) to L-methionine sulfoxide (L-Met-O) by chemical agents, such as iodine, iodate, and hydrogen peroxide, was first demonstrated in 1938 [1]. Because of the chirality of sulfur, two diastereomers, L-Met-O (S) and L-Met-O (R), will be formed in equal volumes when L-Met is oxidized. Later, it was found by Bernett that the growth of rats is restrained when the L-Met in their diet is replaced by L-Met sulfone, whereas, it is not obstructed by L-Met-O [2]. Because free L-Met-O is unable to be inserted into polypeptides during protein synthesis, because methionyl-tRNA synthetase does not recognize it [3]. These observations indicate that L-Met-O but not sulfone could probably be converted back into L-Met in a mechanism, which was unknown at that point.

In the 1970s, the L-Met-O residue in protein was detected, for example, in the human crystallin lens during development of senile nuclear cataracts [4]. Further study showed that the consequence of L-Met oxidation of many proteins inhibited their functions $[5,6]$, and there is a thioredoxin- (Trx) and thioredoxin reductase (TXNRD)-dependent mechanism that could convert L-Met-O back to L-Met [7,8]. Finally, in 1981, scientists obtained an enzyme which could reduce L-Met-O when they were studying the Escherichia coli 
(E. coli) ribosome protein 12 , a protein which loses its activity upon oxidation of selected L-Met residues by hydrogen peroxide [9]. This enzyme was named peptide L-Met-O reductase [10,11] (for review, please refer to [12]).

With the development of genetic cloning technology, in the early 1990s, scientists successfully identified MsrA in bovines and humans that are homologous to the E. coli peptide L-Met-O reductase, and found that MsrA is able to reduce both free and proteinbound L-Met-O [13-15]. During the same time, an MsrA and Trx homologous protein in Neisseria gonorrhoeae called PilB was found to be enzymatically active toward both L-Met-O $(R)$ and L-Met-O (S) [16]. This further lead to the identification of human MsrB1 and MsrB2. MsrB1 was discovered first as a selenoprotein $[17,18]$; its homology to PilB made scientists rename it from selenoprotein $\mathrm{R} / \mathrm{X}$ to MsrB1. Meanwhile, MsrB2 was first named CBS-1, for it was identified by searching for the PilB similar genes by using the c-DNA library of the human ciliary body [19]. Thereafter, the stereoselectivity of Msrs was reported. MsrA was found to stereo-specifically reduce L-Met-O (S) [20], whereas, MsrB could only reduce L-Met-O $(R)$ in proteins [21]. Following the discovery of MsrB3 [22], the mammalian Msr family has been carefully studied during the past two decades. Many Msr gene knockout (KO) mouse models have been developed. Each model displays unique features, indicating their functions could not be compensated by one another. Previously, we observed that the loss of MsrB1 impairs the spatial learning activity of mice, which is very similar to the phenotype derived from selenium-deficient diet feeding mice. In this review, we focused on summarizing the observations we obtained from MsrB1 $\mathrm{KO}$ mice, with the expectation of helping readers and ourselves to better understand how the trace element selenium becomes involved in regulating L-Met-O reduction (Figure 1) and synaptic plasticity.

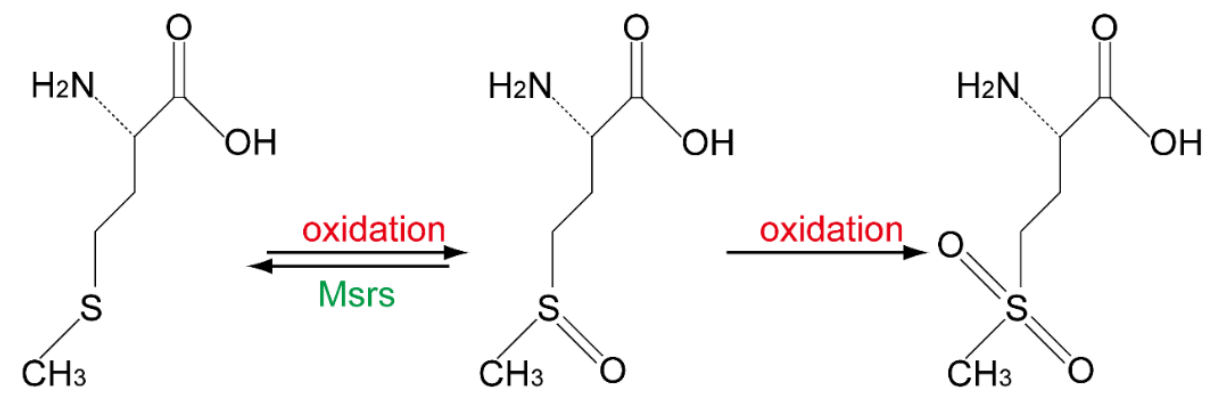

Figure 1. Methionine residue can be oxidized into methionine sulfoxide by, e.g., ROS and further oxidized into methionine sulfone by, e.g., performic acid; however, only methionine sulfoxide can be reduced back into methionine by methionine sulfoxide reductase (Msr) in a stereospecific manner.

\section{Loss of Msr Resulted in Different Phenotype in Mice}

MsrA in mammals is widely distributed in the cytoplasm, nucleus, and mitochondria. Whereas MsrB1 is in cytoplasm and nucleus, MsrB2 is found in the matrix of mitochondria, and MsrB3 is mainly found in the endoplasmic reticulum (Table 1). Moreover, in isolated primary neurons, astrocytes, and microglia from mice brains, by using q-PCR to examine the mRNA levels of Msr, it was found that all Msrs are highly expressed in astrocytes, especially MsrB2 and MsrB3, and the mRNA levels of these two in astrocytes are 10 times higher than those in neurons and microglia. However, the mRNA level of MsrB1 in astrocytes is similar to in microglia and both of them are only slightly higher than that in neurons [23].

The knockout of MsrA in mice leads to difficulties in learning complex tasks, such as in operant learning tests, in which $\mathrm{MsrA}^{-/-}$mice manifest significantly slower learning of how to press levers multiple times to receive rewards than wild-type mice. This is probably because of the degeneration of neurons in the hippocampal areas, and the abnormal dopamine levels in brain tissue, along with lower locomotive activities. These mice also exhibit a tip-toe walking pattern after six months of age [24]. In hyperbaric oxygen conditions, the cytochrome $\mathrm{C}$ in the lens of MsrA deficiency mice is readily oxidized at 
Met-65 and Met-80 residues, leading to the aggregation and decomposition of cytochrome $\mathrm{C}$, and eventually the development of cataracts [25]. Moreover, MsrA knockout has been reported to shorten the lifespan of mice [26], but this observation is quite controversial [27]. Recently, it has also been shown that MsrA knockout mice exhibit progressive hearing loss and sensitivity to acoustic trauma [28].

In 2013, it was reported that MsrB1 could reduce oxidized actin, thus rescuing the polymerization activity of actin in vitro [29]. However, loss of MsrB1 in mice did not severely perturb the development, though the levels of malondialdehyde, protein carbonyl and methionine sulfoxide, lipid peroxidation, and oxidized glutathione were significantly increased in their livers and kidneys [30]. Moreover, the deficiency of MsrB1 exacerbates acetaminophen-induced hepatotoxicity represented by increased hydrogen peroxide production, lipid peroxidation, and protein oxidation levels [31]. Meanwhile, after being treated by LPS, the anti-inflammatory cytokines produced by macrophages are reduced in MsrB1 knockout models [32]. Recently, it was observed that the loss of MsrB1 induces astrogliosis in mouse brains, along with an impairment of spatial learning activity. The brain slices of these mice displayed downregulated long-term potentiation (LTP) due to the dephosphorylation of CaMKII $\alpha / \beta$ [23].

MsrB2 KO mice models have also been developed recently. Global KO in mice decreases platelets [33]. The depletion of MsrB2 platelets leads to reduced mitophagy and increased platelet apoptosis because of the oxidation of Parkin. In terms of MsrB3, it has been found that MsrB3 knockout induces static-ciliary tract degeneration and cochlear hair cell apoptosis, which eventually results in hearing loss in mice [34] (Table 1). These observations indicate that each Msrs has some unique functions and cannot be completely replaced by others. Though each of the three MsrBs can reduce L-Met-O $(R)$, the substrates of each are different.

Table 1. The phenotypes of Msrs knockout (KO) mice.

\begin{tabular}{|c|c|c|c|}
\hline Msrs & Substrate & Subcellular Localization & Phenotype of KO Mice \\
\hline MsrA & $\begin{array}{l}\text { L-Met-O }(S) \text { in or free } \\
\text { of proteins [35] }\end{array}$ & $\begin{array}{l}\text { Cytoplasm, nucleus, } \\
\text { mitochondria }[36,37]\end{array}$ & $\begin{array}{c}\text { Learning disability, motor } \\
\text { behavior disorders, } \\
\text { progressive hearing } \\
\text { loss [28] }\end{array}$ \\
\hline MsrB1 & $\begin{array}{l}\text { L-Met-O }(R) \text { in } \\
\text { proteins }\end{array}$ & Cytoplasm, nucleus [30] & $\begin{array}{c}\text { Oxidative stress increase in } \\
\text { kidney and liver [30], } \\
\text { learning and memory } \\
\text { disability [23] }\end{array}$ \\
\hline MsrB2 & $\begin{array}{l}\text { L-Met-O }(R) \text { in } \\
\text { proteins }\end{array}$ & Mitochondria [38] & $\begin{array}{c}\text { Increased platelet } \\
\text { apoptosis [33] }\end{array}$ \\
\hline MsrB3 & $\begin{array}{l}\text { L-Met-O }(R) \text { in } \\
\text { proteins }\end{array}$ & Endoplasmic reticulum [22] & Hearing loss [34] \\
\hline
\end{tabular}

\section{Deficiency of Selenium or Selenoproteins Results in Disfunction of the Brain}

Selenium used to be considered as a toxic chemical, for it was involved in the "alkali disease" in livestock [39] and excessive selenium intake caused hair and nail loss in humans [40]. However, this viewpoint was overturned upon the discovery of the essentiality of this element in rats [41] and E. coli [42]. Thereafter, it was found that selenium could be synthetized into proteins via Selenocysteine (Sec), the 21st amino acid in nature, which is encoded by the stop codon UGA [43].

In terms of Sec, it cannot be simply regarded as a cysteine in which the element sulfur is replaced by selenium. In fact, synthesis of Sec starts on the phosphorylated-serine-tRNA. $\mathrm{HSe}^{-}$is catalyzed into $\mathrm{SeH}_{2} \mathrm{PO}_{3}{ }^{-}$by selenophosphate synthetase 2 (SEPHS2), then Sec synthase (SecS) connects $\mathrm{SeHPO}_{3}{ }^{-}$and phosphorylated-serine-tRNA to form Sec-tRNA (for review, please refer to [44]). As mentioned above, Sec is encoded by UGA. To insert Sec-tRNA into this stop codon in the mRNA of the corresponding selenoprotein, a special stem-loop structure called a Sec insertion sequence (SECIS) in the 3'-untranslated 
regions of the mRNA is essential. The help of trans-acting factors, such as Sec-specific elongation factor (EFsec) and SECIS binding protein (SBP2), is also necessary (for review, please refer to [44]). To date, 25 selenoprotein genes have been characterized by searching for the SECIS in human genome, and their translation products include glutathione peroxidases (GPX)1 4,6 and TXNRD1 3 and iodothyronine deiodinases (DIO)1 3, SEPHS2, SELENOF, SELENOH, SELENOI, SELENOK, SELENOM, SELENON, SELENOO, SELENOP, SELENOS, SELENOT, SELENOV, SELENOW, and MsrB1 [45]. However, the functions of many of them are still obscure to date.

As mentioned above, the reducing activity of Msrs is dependent on the existence of Trx and TXNRDs, as well as the cofactor NADPH. All of the human TXNRDs are selenoproteins. TXNRD1 is located in cytosol, while TXNRD2 is distributed in mitochondria. Both of them are widely expressed in variant tissues and cell types; however, TNDRD3 is only found in testes [46]. Due to the knockout of TXNRD1 [47] or TXNRD 2 [48], causing early embryonic death, neuronal cell line-specifically TXNDRD 1 or TXNRD2-depletion is needed to further demonstrate their impact on the brain.

Selenoprotein $\mathrm{P}$ is one of the best studied selenoproteins so far. It contains 10 selenocysteins in humans and is believed to be responsible for selenium transportation, especially for the retention of selenium by the brain [49]. Deletion of the mouse selenoprotein $P$ encoding gene SELENOP remarkedly decreases brain selenium content [50-52]. In addition, SELENOP knockout results in altered hippocampus synaptic function represented by disrupted spatial learning activity. Moreover, the ablation of ApoER2, the receptor of selenoprotein $P$ that facilitates its uptake, also leads to abnormal neurological consequences, which is similar to the phenotypes derived from selenoprotein P deficiency [53]. These observations are also in line with the results that synaptic transmission is altered in wild-type mice that have been fed with a selenium-deficient diet [52,54].

Besides selenoprotein $\mathrm{P}$, selenoprotein $\mathrm{T}$ deficiency also showed serious influence in mice. Global knockout SELENOT resulted in embryonic death. Conditional depletion of SELENOT in neuron lead to reduced volume of different brain structures, including hippocampus, cerebellum, and cerebral cortex, and triggered a hyperactive behavior [55]. In addition, mutation of SecS, which catalyzed the formation of sec-tRNA, produced progressive cerebro-cerebellar atrophy (PCCA), an autosomal recessive disorder resulting in severe brain abnormalities [56]. These studies indicated that selenium and selenoproteins play important roles in brain development and functions.

\section{The Mystery Underlying the Impairment of Synaptic Plasticity in Selenium-Deficient Mice}

The levels of selenium in the liver and kidney are sensitive to dietary selenium, but the level of selenium in the brain can remain normal under the condition of low selenium in the diet. This is because the transport of selenium to the brain is mainly dependent on selenoprotein $\mathrm{P}$ and its receptor [57], whereas the levels of selenium in periphery organisms are directly from ingestion. As mentioned before, depletion of SELENOP and its receptor $A p o E R 2$ results in decreased spatial memory ability in mice, as well as defects in synaptic transmission and LTP $[52,53]$. At present, the molecular mechanisms underlying these observations remain unclear. Given that the level of MsrB1 is quite dependent on the selenium diet supply [30], the deficiency of MsrB1 may be involved in the neurological disfunctions elicited by the knockout of SELENOP and its receptor ApoER2, as well as a selenium-deficient diet. It can be imagined that SELENOP knockout not only reduces selenium levels in brain tissue, but may also affect the expression of many selenium proteins, including MsrB1.

Previously, MsrB1 was found to interact with clusterin (CLU) by yeast two-hybrid screening [58]. The expression of CLU is closely related to the occurrence of Alzheimer's disease (AD) [59]. The results from another laboratory showed that MsrB1 can also interact with transient receptor potential channel M6 (TRPM6) [60]. When treated with hydrogen peroxide, Met1755 of TRPM6 is oxidized, while MsrB1 is able to protect the viability of TRPM6 and to reduce the damage caused by hydrogen peroxide [60]. Our previous research 
showed that in the hippocampus of MsrB1 KO mice, the phosphorylation of CaMKII $\alpha$ and CaMKII $\beta$ was significantly decreased [23]. However, whether MsrB1 directly interacts with CaMKII $\alpha$ and CaMKII $\beta$ is unknown. Thus, recently, we further tested the interaction of murine MsrB1, in which selenocysteine was mutated to cysteine with CaMKII $\alpha$ and CaMKII $\beta$ by yeast two-hybrid screening (Figure 2). It was shown that MsrB1 could indeed interact with both CaMKII $\alpha$ and CaMKII $\beta$ directly.

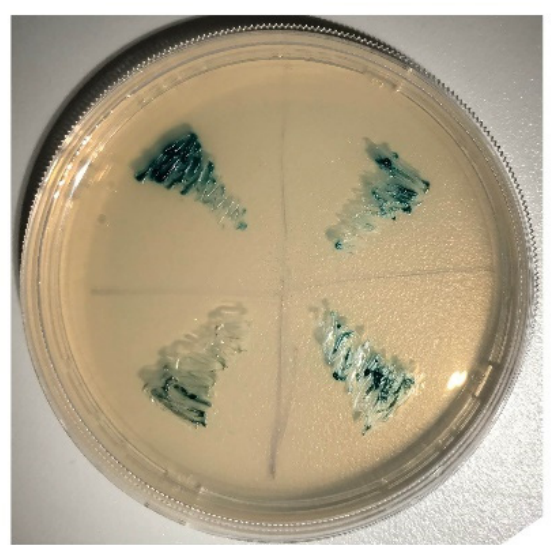

MsrB1 vs CaMKIl $\alpha$

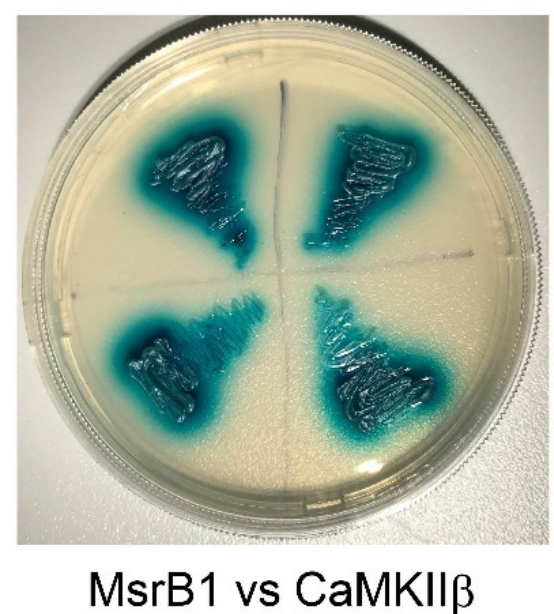

MsrB1 vs CaMKII $\beta$

Figure 2. The interaction of MsrB1 with CaMKII $\alpha$ and CaMKII $\beta$ demonstrated by yeast twohybrid screening.

It had been well established that synaptic plasticity, which could be represented by both LTP and long-term depression (LTD) in electrophysiology methods, is quite dependent on the phosphorylation of CaMKII $\alpha$ and CaMKII $\beta$ [61]. $\mathrm{Ca}^{2+}$ influx could induce the autophosphorylation of CaMKII $\alpha$ and CaMKII $\beta$ at Thr286/Thr286, respectively. In turn, the activation of CaMKII enhanced the synaptic activity of amino-3-hydroxy-5-methyl4-isoxazoleprotionic acid receptors (AMPAR), thereby strengthening the LTP [62]. Most methionine oxidation is known to disrupt the normal function of proteins; however, the CaMKII is activated by methionine oxidation and it can be reduced by MsrA [63]. Though, the activity induced by oxidation is much lower than that is triggered by phosphorylation.

It is worth noting that the oxidation site of CaMKII $\alpha$ and CaMKII $\beta$ at Met280/281 is very close to their autophosphorylation site Thr286/287, respectively. It has also been detected that prolonged exposure to nitric oxide impairs CaMKII activity by reducing the autophosphorylation at Thr286 [64]. By collecting this evidence and our observations in MsrB1 KO mice, we propose that MsrB1 is involved in regulating synaptic plasticity by reducing oxidized CaMKII $\alpha$ and CaMKII $\beta$. As shown in the schematic description (Figure 3), a transmitter such as glutamate activates the ion channel n-methyl-d-aspartate receptor (NMDAR) and induces $\mathrm{Ca}^{2+}$ influx. $\mathrm{Ca}^{2+} /$ calmodulin further triggers the autophosphorylation of CaMKII, which could subsequently enhance the synaptic activity by recruiting AMPAR. However, excessive ions could induce the production of ROS by mitochondria. As a result, the overloaded ROS oxidizes CaMKII, which perturbs the autonomous modulation of CaMKII. In case of impairing the function of CaMKII, MsrA and MsrB1 in cytosol need to exert their reductive activity to restore the function of CaMKII. Therefore, in the following scenarios, such as the deficiency of selenium in the diet, the KO of SELENOP and its receptor, as well as the loss of MsrB1 or MsrA, synaptic plasticity is broken. 


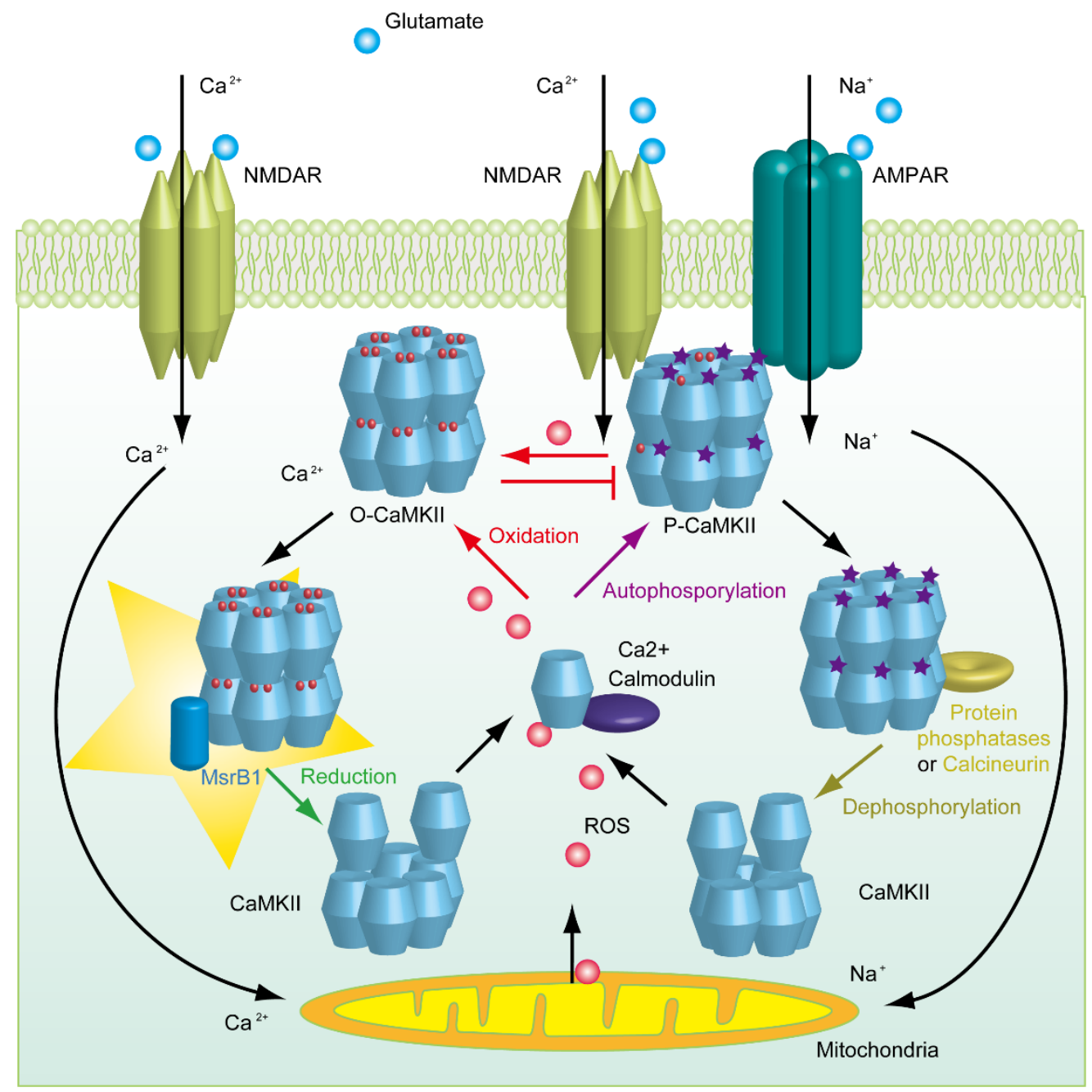

Figure 3. Schematic description of the hypothesis of how MsrB1 is involved in synaptic plasticity. The autophosphorylation of CaMKII could be triggered by $\mathrm{Ca}^{2+} /$ calmodulin in an excited neuron. However, the overload of $\mathrm{Ca}^{2+}$ could induce excitatory toxicity, including the production of ROS by mitochondria, which could further oxidize CaMKII and perturb the phosphorylation of CaMKII. Therefore, synaptic plasticity would be impaired by excessive ROS. Meanwhile, MsrB1 could reduce the oxidized methionine residue in CaMKII and subsequently rescue the synaptic plasticity.

\section{Perspectives}

Due to the high expression level of MsrB1 in the liver and kidney, more attention has been paid to its protective effect under oxidative stress previously. However, recent studies have shown that the expression of MsrB1 in vitro can reduce the methionine sulfoxide at positions 44 and 47 residues of actin. Met44/47 of actin can be oxidized by Micals into L-Met-O, thereby causing changes in spatial conformation and inhibiting its aggregation ability [65], while MsrB1 can restore the aggregation ability of actin by reducing these L-Met-O [29]. However, it is not clear whether Micals and MsrB1 are involved in regulating neuronal plasticity through mediating the redox of actin.

Many clues indicate that Msrs plays a very important role in the central nervous system and is closely related to the occurrence and development of neurodegenerative diseases. For example, when MsrA is depleted in Alzheimer's disease (AD) model mice, the level of amyloid-beta $(A \beta)$ significantly increases, indicating that MsrA can directly regulate the oxidation state of $A \beta$ and transform soluble $A \beta$ into aggregated $A \beta$. It is generally believed that soluble $A \beta$ oligomer has more severe neuronal toxicity, thus MsrA has neuronal protective activity during the pathological process of AD [66]. In addition, Adams et al. reported that MsrB3 is one of the genes related to hippocampus formation 
and volume. In the normal human hippocampus, MsrB3 is highly expressed in pyramidal neurons of stratum lucidum in the CA3 region, but less in the CA1 region, while the expression level in the neurons of the CA1 region is increased in AD patients and AD rat models [67].

$\mathrm{AD}$ is one of the most dramatic neurodegenerative diseases, and according to onset time, AD is divided into early-onset/familial AD and late-onset/sporadic AD. The former group accounts for approximately $5 \%$ of the total number of AD patients, those who develop AD at an early age (24-65 years) and often carry genetic mutations associated with excessive production of $A \beta$, especially $A \beta 1-42$, such as the mutation in $A \beta$ precursor protein (APP) and APP shearing enzyme presenilin-1/2 [68]. The latter group usually develop $\mathrm{AD}$ after the age of 65 , accounting for $~ 95 \%$ of all AD patients and making up the largest group of dementia patients. Through genome-wide association studies and other methods, it has been found that many genes related to lipid metabolism, immune response, and endocytosis are correlated with the occurrence of late-onset AD, including APOE, TREM2, PICALM, and CLU. The exact relationship between these proteins' mutation with $\mathrm{AD}$ remains not fully understood, but some experiments have shown that most of these mutations cause A $\beta$ clearance dysfunction [69]. Thus, the "amyloid cascade hypothesis" has long been dominant in the study of AD etiology. Taking multiple technologies, such as FRET, Co-IP, and pull down, it had been found that MsrB1 can directly interact with A $\beta 1-42$, suggesting a high possibility that MsrB1 may affect the aggregation capacity of $A \beta$ through the regulation of oxidative modification of $A \beta$ [70], which is very similar to the function of MsrA.

The drugs that inhibit the production and aggregation of $A \beta$ failed to achieve clinical success in curing $\mathrm{AD}[71,72]$. On the way for looking for new therapeutic targets of AD, calcium hypothesis was introduced, proposing that the destruction of the calcium steady state is a major cause of AD, and it was reported that calcium concentration in endoplasmic reticulum is highly increased in AD patients [73]. This further leads to the dysfunction of the downstream signal path and LTP/LTD, finally resulting in the loss of synapses and the degeneration of neurons [74]. Neurons are very sensitive to calcium concentrations, and even a slight disorder of the calcium level would cause neurological dysfunction [75,76]. A variety of calcium channels exist on the membrane, such as voltage-gated $\mathrm{Ca}^{2+}$ channels (VGCCs), calcium releasing-activated channels (CRACs), and non-selective cation channels, such as NMDAR, AMPAR, transient receptor potential (TRP), ryanodine sensors (RyR), and 1,4,5-inositol trisphosphate receptor (IP3R). Among them, the effect of A $\beta$ on NMDAR has been widely studied. It has been shown that NMDAR is overactivated in the early stage of $\mathrm{AD}$, resulting in an increase of the calcium concentration in neurons [77]. Memantine, a non-competitive inhibitor of NMDAR has thus been approved for AD treatment by the Food and Drug Administration (FDA) [78].

Previous studies have shown that adding selenomethionine to AD mice diet can effectively reduce the deposition of $\mathrm{A} \beta$ in the brain, inhibit Tau phosphorylation by regulating GSK3 $\beta$ activity, and promote the removal of Tau through autophagy pathway [79-81], thus improving the cognitive and memory abilities of AD model mice. It is also noteworthy that the methylation of PP2A, which could mediate the dephosphorylation of Tau [82], at the L309 of its catalytic subunit can potentially increase its activity [83]. However, it was reported recently that sodium selenite decreases the methylation of PP2A [84]. In addition, the selenium supplement could effectively inhibit ROS-mediated apoptotic neural precursor cell death [85] and promote the neurosphere viability, development, and differentiation [86]. This suggests that selenoproteins may improve the pathological process of AD through multiple pathways. However, since the function of some selenoproteins in the central nervous system is still unclear, the related molecular biological mechanism needs to be further explored. Moreover, it has also been reported that the supplementation of selenium does not forestall dementia in clinical research [87], and combined with our unpublished proteomics data, we speculate that the disagreement of these observations may be because of the different forms of selenium that were used in these studies. Therefore, 
this demands attention on the differences between the ingestion of inorganic and organic selenium and their subsequent biological effects in this field. Moreover, AD mice models are artificially enforced to express mutated genes derived from familial AD, while $~ 95 \%$ of $\mathrm{AD}$ patients are late-onset sporadic cases, as mentioned before, and the etiopathology of sporadic cases may be distinct from that of familial cases. Thus, the effects of selenium supplementation for AD mice models and crowds of people may be different.

Many studies about Msrs indicate that the reduction and clearance of methionine sulfoxide is essential for maintaining the normal function of the central nervous system. Our previous results showed that MsrB1 is highly expressed in neurocytes and the deficiency of MsrB1 perturbs spatial learning and LTP/LTD in mice [23], but the mechanism of exploration is not sufficient. In vitro, it has been demonstrated that MsrB1 could specifically reduce methionine sulfoxide at positions 44 and 47 residues of actin, thus restoring its ability to polymerize into F-actin. Additionally, if MsrB1 could also exert such a direct role in vivo, then MsrB1 may play an important role in regulating neuronal synaptic formation, immune cell migration, tumor cell proliferation, and other pathological processes. Therefore, further exploration of the physiological role of MsrB1 will be helpful for understanding the function of selenium in the central nervous system and the treatment of neurodegenerative diseases.

Author Contributions: Conceptualization, N.L. and Q.L.; methodology, N.L., Y.Y.; validation, N.L. and Q.L.; formal analysis, N.L.; investigation, T.S. and G.Y.; writing—original draft preparation, T.S.; writing - review and editing, N.L.; visualization, J.S.; supervision, N.L.; project administration, T.S., G.Y., and J.S.; funding acquisition, N.L. and Q.L. All authors have read and agreed to the published version of the manuscript.

Funding: This research was funded by National Natural Science Foundation of China, grant number 21877081; 31700919; the Shenzhen Science and Technology Innovation Commission, grant number JCYJ20180507182417779, and the Shenzhen-Hong Kong Institute of Brain Science-Shenzhen Fundamental Research Institutions, grant number 2019SHIBS0003.

Institutional Review Board Statement: Not applicable.

Informed Consent Statement: Not applicable.

Data Availability Statement: Please The data are available from the authors upon request.

Acknowledgments: We are grateful for generously providing MsrB1 knockout mice by Vadim N. Gladyshev (Brigham and women's hospital, Harvard Medical School).

Conflicts of Interest: The authors declare no conflict of interest. The funders had no role in the design of the study; in the collection, analyses, or interpretation of data; in the writing of the manuscript, or in the decision to publish the results.

Sample Availability: Samples of the mutated MsrB1 plasmid is available from the authors.

\section{References}

1. Toennies, G.A. Sulfoxide of Methionine. Science 1938, 88, 545-546. [CrossRef]

2. Bennett, M.A. Metabolism of sulphur: The replaceability of dl-methionine in the diet of albino rats with its partially oxidized derivative, dl-methionine sulphoxide. Biochem. J. 1939, 33, 1794-1797. [CrossRef]

3. Lemoine, F.; Waller, J.P.; Van Rapenbusch, R. Studies on methionyl transfer RNA synthetase. 1. Purification and some properties of methionyl transfer RNA synthetase from Escherichia coli K-12. Eur. J. Biochem. 1968, 4, 213-221. [CrossRef]

4. Truscott, R.J.; Augusteyn, R.C. Oxidative changes in human lens proteins during senile nuclear cataract formation. Biochim. Biophys. Acta 1977, 492, 43-52. [CrossRef]

5. Swaim, M.W.; Pizzo, S.V. Methionine sulfoxide and the oxidative regulation of plasma proteinase inhibitors. J. Leukoc. Biol. 1988, 43, 365-379. [CrossRef]

6. Johnson, D.; Travis, J. Structural evidence for methionine at the reactive site of human alpha-1-proteinase inhibitor. J. Biol. Chem. 1978, 253, 7142-7144. [CrossRef]

7. Gonzalez Porque, P.; Baldesten, A.; Reichard, P. The involvement of the thioredoxin system in the reduction of methionine sulfoxide and sulfate. J. Biol. Chem. 1970, 245, 2371-2374. [CrossRef]

8. Ejiri, S.I.; Weissbach, H.; Brot, N. The purification of methionine sulfoxide reductase from Escherichia coli. Anal. Biochem. 1980, 102, 393-398. [CrossRef] 
9. Brot, N.; Weissbach, L.; Werth, J.; Weissbach, H. Enzymatic reduction of protein-bound methionine sulfoxide. Proc. Natl. Acad. Sci. USA 1981, 78, 2155-2158. [CrossRef] [PubMed]

10. Brot, N.; Werth, J.; Koster, D.; Weissbach, H. Reduction of N-acetyl methionine sulfoxide: A simple assay for peptide methionine sulfoxide reductase. Anal. Biochem. 1982, 122, 291-294. [CrossRef]

11. Moskovitz, J.; Weissbach, H.; Brot, N. Cloning the expression of a mammalian gene involved in the reduction of methionine sulfoxide residues in proteins. Proc. Natl. Acad. Sci. USA 1996, 93, 2095-2099. [CrossRef]

12. Achilli, C.; Ciana, A.; Minetti, G. The discovery of methionine sulfoxide reductase enzymes: An historical account and future perspectives. Biofactors 2015, 41, 135-152. [CrossRef] [PubMed]

13. Rahman, M.A.; Moskovitz, J.; Strassman, J.; Weissbach, H.; Brot, N. Physical map location of the peptide methionine sulfoxide reductase gene on the Escherichia coli chromosome. J. Bacteriol. 1994, 176, 1548-1549. [CrossRef] [PubMed]

14. Kuschel, L.; Hansel, A.; Schönherr, R.; Weissbach, H.; Brot, N.; Hoshi, T.; Heinemann, S.H. Molecular cloning and functional expression of a human peptide methionine sulfoxide reductase (hMsrA). FEBS Lett. 1999, 456, 17-21. [CrossRef]

15. Grimaud, R.; Ezraty, B.; Mitchell, J.K.; Lafitte, D.; Briand, C.; Derrick, P.J.; Barras, F. Repair of oxidized proteins. Identification of a new methionine sulfoxide reductase. J. Biol. Chem. 2001, 276, 48915-48920. [CrossRef] [PubMed]

16. Wizemann, T.M.; Moskovitz, J.; Pearce, B.J.; Cundell, D.; Arvidson, C.G.; So, M.; Weissbach, H.; Brot, N.; Masure, H.R. Peptide methionine sulfoxide reductase contributes to the maintenance of adhesins in three major pathogens. Proc. Natl. Acad. Sci. USA 1996, 93, 7985-7990. [CrossRef]

17. Kryukov, G.V.; Kryukov, V.M.; Gladyshev, V.N. New mammalian selenocysteine-containing proteins identified with an algorithm that searches for selenocysteine insertion sequence elements. J. Biol. Chem. 1999, 274, 33888-33897. [CrossRef] [PubMed]

18. Lescure, A.; Gautheret, D.; Carbon, P.; Krol, A. Novel selenoproteins identified in silico and in vivo by using a conserved RNA structural motif. J. Biol. Chem. 1999, 274, 38147-38154. [CrossRef]

19. Huang, W.; Escribano, J.; Sarfarazi, M.; Coca-Prados, M. Identification, expression and chromosome localization of a human gene encoding a novel protein with similarity to the pilB family of transcriptional factors (pilin) and to bacterial peptide methionine sulfoxide reductases. Gene 1999, 233, 233-240. [CrossRef]

20. Sharov, V.S.; Ferrington, D.A.; Squier, T.C.; Schoneich, C. Diastereoselective reduction of protein-bound methionine sulfoxide by methionine sulfoxide reductase. FEBS Lett. 1999, 455, 247-250. [CrossRef]

21. Lowther, W.T.; Weissbach, H.; Etienne, F.; Brot, N.; Matthews, B.W. The mirrored methionine sulfoxide reductases of Neisseria gonorrhoeae pilB. Nat. Struct. Biol. 2002, 9, 348-352. [CrossRef] [PubMed]

22. Kim, H.Y.; Gladyshev, V.N. Characterization of mouse endoplasmic reticulum methionine-R-sulfoxide reductase. Biochem. Biophys. Res. Commun. 2004, 320, 1277-1283. [CrossRef]

23. Shi, T.; Yang, Y.; Zhang, Z.; Zhang, L.; Song, J.; Ping, Y.; Du, X.; Song, G.; Liu, Q.; Li, N. Loss of MsrB1 perturbs spatial learning and long-term potentiation/long-term depression in mice. Neurobiol. Learn Mem. 2019, 166, 107104. [CrossRef] [PubMed]

24. Oien, D.B.; Osterhaus, G.L.; Latif, S.A.; Pinkston, J.W.; Fulks, J.; Johnson, M.; Fowler, S.C.; Moskovitz, J. MsrA knockout mouse exhibits abnormal behavior and brain dopamine levels. Free Radic. Biol. Med. 2008, 45, 193-200. [CrossRef] [PubMed]

25. Brennan, L.A.; Lee, W.; Cowell, T.; Giblin, F.; Kantorow, M. Deletion of mouse MsrA results in HBO-induced cataract: MsrA repairs mitochondrial cytochrome c. Mol. Vis. 2009, 15, 985-999. [PubMed]

26. Moskovitz, J.; Bar-Noy, S.; Williams, W.M.; Requena, J.; Berlett, B.S.; Stadtman, E.R. Methionine sulfoxide reductase (MsrA) is a regulator of antioxidant defense and lifespan in mammals. Proc. Natl. Acad. Sci. USA 2001, 98, 12920-12925. [CrossRef]

27. Salmon, A.B.; Pérez, V.I.; Bokov, A.; Jernigan, A.; Kim, G.; Zhao, H.; Levine, R.L.; Richardson, A. Lack of methionine sulfoxide reductase A in mice increases sensitivity to oxidative stress but does not diminish life span. Faseb J. 2009, 23, 3601-3608. [CrossRef]

28. Alqudah, S.; Chertoff, M.; Durham, D.; Moskovitz, J.; Staecker, H.; Peppi, M. Methionine Sulfoxide Reductase A Knockout Mice Show Progressive Hearing Loss and Sensitivity to Acoustic Trauma. Audiol. Neurootol. 2018, 23, 20-31. [CrossRef]

29. Lee, B.C.; Péterfi, Z.; Hoffmann, F.W.; Moore, R.E.; Kaya, A.; Avanesov, A.; Tarrago, L.; Zhou, Y.; Weerapana, E.; Fomenko, D.E.; et al. MsrB1 and MICALs regulate actin assembly and macrophage function via reversible stereoselective methionine oxidation. Mol. Cell. 2013, 51, 397-404. [CrossRef]

30. Fomenko, D.E.; Novoselov, S.V.; Natarajan, S.K.; Lee, B.C.; Koc, A.; Carlson, B.A.; Lee, T.H.; Kim, H.Y.; Hatfield, D.L.; Gladyshev, V.N. MsrB1 (methionine-R-sulfoxide reductase 1) knock-out mice: Roles of MsrB1 in redox regulation and identification of a novel selenoprotein form. J. Biol. Chem. 2009, 284, 5986-5993. [CrossRef]

31. Kim, K.Y.; Kwak, G.H.; Singh, M.P.; Gladyshev, V.N.; Kim, H.Y. Selenoprotein MsrB1 deficiency exacerbates acetaminopheninduced hepatotoxicity via increased oxidative damage. Arch. Biochem. Biophys. 2017, 634, 69-75. [CrossRef]

32. Lee, B.C.; Lee, S.G.; Choo, M.K.; Kim, J.H.; Lee, H.M.; Kim, S.; Fomenko, D.E.; Kim, H.Y.; Park, J.M.; Gladyshev, V.N. Selenoprotein MsrB1 promotes anti-inflammatory cytokine gene expression in macrophages and controls immune response in vivo. Sci. Rep. 2017, 7, 5119. [CrossRef] [PubMed]

33. Lee, S.H.; Lee, S.; Du, J.; Jain, K.; Ding, M.; Kadado, A.J.; Atteya, G.; Jaji, Z.; Tyagi, T.; Kim, W.H.; et al. Mitochondrial MsrB2 serves as a switch and transducer for mitophagy. EMBO. Mol. Med. 2019, 11, e10409. [CrossRef]

34. Kwon, T.J.; Cho, H.J.; Kim, U.K.; Lee, E.; Oh, S.K.; Bok, J.; Bae, Y.C.; Yi, J.K.; Lee, J.W.; Ryoo, Z.Y.; et al. Methionine sulfoxide reductase B3 deficiency causes hearing loss due to stereocilia degeneration and apoptotic cell death in cochlear hair cells. Hum. Mol. Genet. 2014, 23, 1591-1601. [CrossRef] 
35. Moskovitz, J.; Poston, J.M.; Berlett, B.S.; Nosworthy, N.J.; Szczepanowski, R.; Stadtman, E.R. Identification and characterization of a putative active site for peptide methionine sulfoxide reductase (MsrA) and its substrate stereospecificity. J. Biol. Chem. 2000, 275, 14167-14172. [CrossRef] [PubMed]

36. Kim, H.Y.; Gladyshev, V.N. Role of structural and functional elements of mouse methionine-S-sulfoxide reductase in its subcellular distribution. Biochemistry 2005, 44, 8059-8067. [CrossRef]

37. Haenold, R.; Wassef, R.; Hansel, A.; Heinemann, S.H.; Hoshi, T. Identification of a new functional splice variant of the enzyme methionine sulphoxide reductase A (MSRA) expressed in rat vascular smooth muscle cells. Free Radic. Res. 2007, 41, 1233-1245. [CrossRef] [PubMed]

38. Cabreiro, F.; Picot, C.R.; Perichon, M.; Castel, J.; Friguet, B.; Petropoulos, I. Overexpression of mitochondrial methionine sulfoxide reductase B2 protects leukemia cells from oxidative stress-induced cell death and protein damage. J. Biol. Chem. 2008, 283, 16673-16681. [CrossRef] [PubMed]

39. Reich, H.J.; Hondal, R.J. Why Nature Chose Selenium. ACS Chem. Biol. 2016, 11, 821-841. [CrossRef] [PubMed]

40. Vinceti, M.; Wei, E.T.; Malagoli, C.; Bergomi, M.; Vivoli, G. Adverse health effects of selenium in humans. Rev. Environ. Health 2001, 16, 233-251. [CrossRef] [PubMed]

41. Aterman, K. Selenium and liver necrosis in the hyperthyroid rat. Nature 1958, 182, 1514. [CrossRef]

42. Pinsent, J. The need for selenite and molybdate in the formation of formic dehydrogenase by members of the coli-aerogenes group of bacteria. Biochem. J. 1954, 57, 10-16. [CrossRef] [PubMed]

43. Neve, J.; Vertongen, F.; Molle, L. Selenium deficiency. Clin. Endocrinol. Metab. 1985, 14, 629-656. [CrossRef]

44. Labunskyy, V.M.; Hatfield, D.L.; Gladyshev, V.N. Selenoproteins: Molecular pathways and physiological roles. Physiol. Rev. 2014, 94, 739-777. [CrossRef] [PubMed]

45. Gladyshev, V.N.; Arner, E.S.; Berry, M.J.; Brigelius-Flohe, R.; Bruford, E.A.; Burk, R.F.; Carlson, B.A.; Castellano, S.; Chavatte, L.; Conrad, M.; et al. Selenoprotein Gene Nomenclature. J. Biol. Chem. 2016, 291, 24036-24040. [CrossRef] [PubMed]

46. Soerensen, J.; Jakupoglu, C.; Beck, H.; Forster, H.; Schmidt, J.; Schmahl, W.; Schweizer, U.; Conrad, M.; Brielmeier, M. The role of thioredoxin reductases in brain development. PLoS ONE 2008, 3, e1813. [CrossRef]

47. Jakupoglu, C.; Przemeck, G.K.H.; Schneider, M.; Moreno, S.G.; Mayr, N.; Hatzopoulos, A.K.; De Angelis, M.H.; Wurst, W.; Bornkamm, G.W.; Brielmeier, M.; et al. Cytoplasmic thioredoxin reductase is essential for embryogenesis but dispensable for cardiac development. Mol. Cell. Biol. 2005, 25, 1980-1988. [CrossRef]

48. Conrad, M.; Jakupoglu, C.; Moreno, S.G.; Lippl, S.; Banjac, A.; Schneider, M.; Beck, H.; Hatzopoulos, A.K.; Just, U.; Sinowatz, F.; et al. Essential role for mitochondrial thioredoxin reductase in hematopoiesis, heart development, and heart function. Mol. Cell. Biol. 2004, 24, 9414-9423. [CrossRef]

49. Hill, K.E.; Lloyd, R.S.; Yang, J.G.; Read, R.; Burk, R.F. The cDNA for rat selenoprotein P contains 10 TGA codons in the open reading frame. J. Biol. Chem. 1991, 266, 10050-10053. [CrossRef]

50. Hill, K.E.; Zhou, J.; Mcmahan, W.J.; Motley, A.K.; Atkins, J.F.; Gesteland, R.F.; Burk, R.F. Deletion of selenoprotein P alters distribution of selenium in the mouse. J. Biol. Chem. 2003, 278, 13640-13646. [CrossRef]

51. Valentine, W.M.; Hill, K.E.; Austin, L.M.; Valentine, H.L.; Goldowitz, D.; Burk, R.F. Brainstem axonal degeneration in mice with deletion of selenoprotein p. Toxicol. Pathol. 2005, 33, 570-576. [CrossRef]

52. Peters, M.M.; Hill, K.E.; Burk, R.F.; Weeber, E.J. Altered hippocampus synaptic function in selenoprotein P deficient mice. Mol. Neurodegener. 2006, 1, 12. [CrossRef] [PubMed]

53. Burk, R.F.; Hill, K.E.; Olson, G.E.; Weeber, E.J.; Motley, A.K.; Winfrey, V.P.; Austin, L.M. Deletion of apolipoprotein E receptor-2 in mice lowers brain selenium and causes severe neurological dysfunction and death when a low-selenium diet is fed. J. Neurosci. 2007, 27, 6207-6211. [CrossRef]

54. Raman, A.V.; Pitts, M.W.; Seyedali, A.; Hashimoto, A.C.; Seale, L.A.; Bellinger, F.P.; Berry, M.J. Absence of selenoprotein P but not selenocysteine lyase results in severe neurological dysfunction. Genes. Brain. Behav. 2012, 11, 601-613. [CrossRef] [PubMed]

55. Castex, M.T.; Arabo, A.; Benard, M.; Roy, V.; Le Joncour, V.; Prevost, G.; Bonnet, J.J.; Anouar, Y.; Falluel-Morel, A. Selenoprotein T Deficiency Leads to Neurodevelopmental Abnormalities and Hyperactive Behavior in Mice. Mol. Neurobiol. 2016, 53, 5818-5832. [CrossRef] [PubMed]

56. Agamy, O.; Ben Zeev, B.; Lev, D.; Marcus, B.; Fine, D.; Su, D.; Narkis, G.; Ofir, R.; Hoffmann, C.; Leshinsky-Silver, E.; et al. Mutations disrupting selenocysteine formation cause progressive cerebello-cerebral atrophy. Am. J. Hum. Genet. 2010, 87, 538-544. [CrossRef] [PubMed]

57. Schomburg, L.; Schweizer, U.; Holtmann, B.; Flohé, L.; Sendtner, M.; Köhrle, J. Gene disruption discloses role of selenoprotein P in selenium delivery to target tissues. Biochem. J. 2003, 370, 397-402. [CrossRef]

58. Chen, P.; Wang, C.; Ma, X.; Zhang, Y.; Liu, Q.; Qiu, S.; Liu, Q.; Tian, J.; Ni, J. Direct Interaction of Selenoprotein R with Clusterin and Its Possible Role in Alzheimer's Disease. PLoS ONE 2013, 8, e66384. [CrossRef] [PubMed]

59. Harold, D.; Abraham, R.; Hollingworth, P.; Sims, R.; Gerrish, A.; Hamshere, M.L.; Pahwa, J.S.; Moskvina, V.; Dowzell, K.; Williams, A.; et al. Genome-wide association study identifies variants at CLU and PICALM associated with Alzheimer's disease. Nat. Genet. 2009, 41, 1088-1093. [CrossRef]

60. Cao, G.; Lee, K.P.; Van Der Wijst, J.; De Graaf, M.; Van Der Kemp, A.; Bindels, R.J.; Hoenderop, J.G. Methionine sulfoxide reductase B1 (MsrB1) recovers TRPM6 channel activity during oxidative stress. J. Biol. Chem. 2010, 285, 26081-26087. [CrossRef]

61. Bayer, K.U.; Schulman, H. CaM Kinase: Still Inspiring at 40. Neuron 2019, 103, 380-394. [CrossRef] [PubMed] 
62. Huganir, R.L.; Nicoll, R.A. AMPARs and Synaptic Plasticity: The Last 25 Years. Neuron 2013, 80, 704-717. [CrossRef]

63. Erickson, J.R.; Joiner, M.L.; Guan, X.; Kutschke, W.; Yang, J.; Oddis, C.V.; Bartlett, R.K.; Lowe, J.S.; O'donnell, S.E.; Aykin-Burns, N.; et al. A dynamic pathway for calcium-independent activation of CaMKII by methionine oxidation. Cell 2008, 133, 462-474. [CrossRef] [PubMed]

64. Coultrap, S.J.; Bayer, K.U. Nitric Oxide Induces Ca2+-independent Activity of the Ca2+/Calmodulin-dependent Protein Kinase II (CaMKII). J. Bio. Chem. 2014, 289, 19458-19465. [CrossRef]

65. Hung, R.J.; Yazdani, U.; Yoon, J.; Wu, H.; Yang, T.; Gupta, N.; Huang, Z.; Van Berkel, W.J.; Terman, J.R. Mical links semaphorins to F-actin disassembly. Nature 2010, 463, 823-827. [CrossRef]

66. Moskovitz, J.; Du, F.; Bowman, C.F.; Yan, S.S. Methionine sulfoxide reductase A affects beta-amyloid solubility and mitochondrial function in a mouse model of Alzheimer's disease. Am. J. Physiol. Endocrinol. Metab. 2016, 310, E388-E393. [CrossRef]

67. Adams, S.L.; Benayoun, L.; Tilton, K.; Chavez, O.R.; Himali, J.J.; Blusztajn, J.K.; Seshadri, S.; Delalle, I. Methionine Sulfoxide Reductase-B3 (MsrB3) Protein Associates with Synaptic Vesicles and its Expression Changes in the Hippocampi of Alzheimer's Disease Patients. J. Alzheimers Dis. 2017, 60, 43-56. [CrossRef] [PubMed]

68. Mohamed, T.; Shakeri, A.; Rao, P.P. Amyloid cascade in Alzheimer's disease: Recent advances in medicinal chemistry. Eur. J. Med. Chem. 2016, 113, 258-272. [CrossRef]

69. Karch, C.M.; Goate, A.M. Alzheimer's disease risk genes and mechanisms of disease pathogenesis. Biol. Psychiatry 2015, 77, 43-51. [CrossRef] [PubMed]

70. Wang, C.; Chen, P.; He, X.; Peng, Z.; Chen, S.; Zhang, R.; Cheng, J.; Liu, Q. Direct interaction between selenoprotein R and Abeta42. Biochem. Biophys. Res. Commun. 2017, 489, 509-514. [CrossRef] [PubMed]

71. Cummings, J.L.; Morstorf, T.; Zhong, K. Alzheimer's disease drug-development pipeline: Few candidates, frequent failures. Alzheimers Res. Ther. 2014, 6, 37. [CrossRef] [PubMed]

72. Cummings, J.; Lee, G.; Mortsdorf, T.; Ritter, A.; Zhong, K. Alzheimer's disease drug development pipeline: 2017. Alzheimers Dement (NY) 2017, 3, 367-384. [CrossRef] [PubMed]

73. Bezprozvanny, I.; Mattson, M.P. Neuronal calcium mishandling and the pathogenesis of Alzheimer's disease. Trends Neurosci. 2008, 31, 454-463. [CrossRef]

74. Popugaeva, E.; Pchitskaya, E.; Bezprozvanny, I. Dysregulation of neuronal calcium homeostasis in Alzheimer's disease - A therapeutic opportunity? Biochem. Biophys. Res. Commun. 2017, 483, 998-1004. [CrossRef] [PubMed]

75. Kumar, A.; Bodhinathan, K.; Foster, T.C. Susceptibility to Calcium Dysregulation during Brain Aging. Front. Aging Neurosci. 2009, 1, 2. [CrossRef] [PubMed]

76. Bezprozvanny, I. Calcium signaling and neurodegenerative diseases. Trends Mol. Med. 2009, 15, 89-100. [CrossRef]

77. Ferreira, I.L.; Bajouco, L.M.; Mota, S.I.; Auberson, Y.P.; Oliveira, C.R.; Rego, A.C. Amyloid beta peptide 1-42 disturbs intracellular calcium homeostasis through activation of GluN2B-containing N-methyl-d-aspartate receptors in cortical cultures. Cell Calcium 2012, 51, 95-106. [CrossRef]

78. Lipton, S.A. Pathologically activated therapeutics for neuroprotection. Nat. Rev. Neurosci. 2007, 8, 803-808. [CrossRef] [PubMed]

79. Song, G.; Zhang, Z.; Wen, L.; Chen, C.; Shi, Q.; Zhang, Y.; Ni, J.; Liu, Q. Selenomethionine ameliorates cognitive decline, reduces tau hyperphosphorylation, and reverses synaptic deficit in the triple transgenic mouse model of Alzheimer's disease. J. Alzheimers Dis. 2014, 41, 85-99. [CrossRef]

80. Zhang, Z.H.; Chen, C.; Wu, Q.Y.; Zheng, R.; Liu, Q.; Ni, J.Z.; Hoffmann, P.R.; Song, G.L. Selenomethionine reduces the deposition of beta-amyloid plaques by modulating beta-secretase and enhancing selenoenzymatic activity in a mouse model of Alzheimer's disease. Metallomics 2016, 8, 782-789. [CrossRef]

81. Zhang, Z.H.; Wu, Q.Y.; Zheng, R.; Chen, C.; Chen, Y.; Liu, Q.; Hoffmann, P.R.; Ni, J.Z.; Song, G.L. Selenomethionine Mitigates Cognitive Decline by Targeting Both Tau Hyperphosphorylation and Autophagic Clearance in an Alzheimer's Disease Mouse Model. J. Neurosci. 2017, 37, 2449-2462. [CrossRef]

82. Goedert, M.; Cohen, E.S.; Jakes, R.; Cohen, P. p42 MAP kinase phosphorylation sites in microtubule-associated protein tau are dephosphorylated by protein phosphatase 2A1. Implications for Alzheimer's disease. FEBS Lett. 1992, 312, 95-99. [CrossRef]

83. Longin, S.; Zwaenepoel, K.; Louis, J.V.; Dilworth, S.; Goris, J.; Janssens, V. Selection of protein phosphatase 2A regulatory Subunits is mediated by the $C$ terminus of the catalytic subunit. J. Biol. Chem. 2007, 282, 26971-26980. [CrossRef] [PubMed]

84. Habbab, W.; Aoude, I.; Palangi, F.; Abdulla, S.; Ahmed, T. The Anti-Tumor Agent Sodium Selenate Decreases Methylated PP2A, Increases GSK3Y216 Phosphorylation, Including Tau Disease Epitopes and Reduces Neuronal Excitability in SHSY-5Y Neurons. Inter. J. Mol. Sci. 2019, 20, 844. [CrossRef] [PubMed]

85. Yeo, J.E.; Kang, S.K. Selenium effectively inhibits ROS-mediated apoptotic neural precursor cell death in vitro and in vivo in traumatic brain injury. Biochim. Biophys. Acta 2007, 1772, 1199-1210. [CrossRef] [PubMed]

86. Tian, D.P.; Su, M.; Wu, X.Y.; Zhang, G. Effects of selenium and B-27 supplements on viability and differentiation of neural stem cell in newborn rat. Zhonghua Yu Fang Yi Xue Za Zhi 2005, 39, 324-327.

87. Kryscio, R.J.; Abner, E.L.; Caban-Holt, A.; Lovell, M.; Goodman, P.; Darke, A.K.; Yee, M.; Crowley, J.; Schmitt, F.A. Association of Antioxidant Supplement Use and Dementia in the Prevention of Alzheimer's Disease by Vitamin E and Selenium Trial (PREADViSE). JAMA Neurol. 2017, 74, 567-573. [CrossRef] 